\title{
Contribution of Dug-Out Wells to Salmonella Dissemination in Kwaebibirem District of Ghana
}

\author{
Feglo, P.K. \\ Medical Sciences, Kwame Nkrumah University of Science and Technology, \\ Kumasi, Ghana \\ Dakorah, M. P.
}

St. Dominic Hospital, Akwatia, Kwaebibirem District, Ghana.

URL:http://dx.doi.org/10.19044/esj.2017.v13n6p124

\begin{abstract}
Typhoid fever is rare in the developed world, but in Kwaebibirem District of Ghana, Salmonella infections are very common. Typhoid and paratyphoid fevers in addition to gastroenteritis are frequently reported. The reservoir, prevailing Salmonella species and their antimicrobial susceptibility patterns are not known, but in Ghana treatment of these infections are mostly empirical. 464 samples ( 270 stool and 194 blood) were collected from patients and 188 water samples were collected from different water sources in Kwaebibirem District and cultured for Salmonella at St. Dominic Hospital, Akwatia. Salmonella prevalence of 11.6\% (54/464) among patients and 2.7\% (5/188) from dug-out wells were obtained. Total viable bacterial count in the water samples averaged $2.56 \times 10^{3}-1.2 \times 10^{13}$ per milliliter. Five (5) out of 51 (9.8\%) dug-out wells yielded Salmonellae upon culture. Typhoidal Salmonellae [11\% (6/54)] and 68.6\% (38/54) non-typhoidal Salmonellae were isolated from patients. The most affected age group ranged 6-15years with prevalence of $42.6 \%(23 / 54)$. The most frequent isolated was Salmonella Typhi 20\% (11/54) followed by Salmonella Enterica, 29.6\% (16/54). The Salmonella isolates were all susceptible to the cephalosporins (cefoxitin, cefotaxime, cefepime) the carbapenems (imipenem and meropenem) the quinolones (norfloxacin and ciprofloxacin) and the aminoglycoside (amikacin). Their resistant proportions to other drugs were ampicillin (69.5\%), piperacillin $(69.5 \%)$ and co-trimoxazole $(76.3 \%)$. Salmonella infections were common in Kwaebibirem District, and home owned dug-out wells posed risk of Salmonella transmission to the people.
\end{abstract}

Keywords: Salmonella infection, typhoid fever, dug-out well, well water, antimicrobial resistance 


\section{Introduction}

Typhoid and paratyphoid infections are common in Kwaebibirem District in Ghana, where it is among the top ten (10) and accounts for about 1054 admissions and more than 200 deaths annually as a result of these infections (CHIM/PPME-GHS, 2014). Meanwhile, the Salmonella types causing the infections and the disease burden are not known. So also the sources of Salmonella spread in Kwaebibirem District are not known. This study was therefore conducted to determine the prevalence of Salmonella infection, the antimicrobial susceptibility patterns of the isolates and to determine whether water constitutes a major source of Salmonella infection to the people of Kwaebibirem District.

This study was conducted after obtaining ethical clearance from the joint committee on Human research, publication and ethics of School of Medical Sciences, KNUST, Kumasi.

\section{Materials and Methods}

This study was conducted at Akwatia in the Kwaebibirem District of the Eastern Region of Ghana from September 2012 to August 2014. The Kwaebibirem District with a land size of $1230 \mathrm{~km}^{2}$, is located on the SouthWestern part of the Eastern region. The District lies in the west semi-equatorial climatic zone with bi-modal rainfall around $1120 \mathrm{~mm}^{3}$. The average temperature ranges between $26.5^{\circ} \mathrm{C}$ in July and $37^{\circ} \mathrm{C}$ in January. Treated water supply to the inhabitants of the district comes from varied sources: Pipe borne water supply is about (37\%), River/stream (22.3\%), Wells (21.6\%), Boreholes $(14.9 \%)$ and Tanker supply services $(0.5 \%)$. The district has a population of 192,562 (a population density of $154 / \mathrm{km} 2$ ). The inhabitants mostly are farmers, but some engage in small scale mining and petty trading. There are also artisans, government and company workers and petty traders (2010 Population \& Housing Census, Summary Report of Final Results, Ghana Statistical Service, 2012). Patients were received from the various parts of the district. Then individuals from whom Salmonella was isolated were traced to their communities. Water samples were collected from the communities, transported to the laboratory in cold box and tested for Salmonella. This was done in an attempt to identify the source of the infection to these individuals.

\section{Culture procedures}

Blood: Non duplicate 194 blood samples were inoculated into trypticase soy broth (Liofilchem, Italy) and incubated at $37^{\circ} \mathrm{C}$ overnight, and then sub-cultured on blood agar and MacConkey agar (Liofilchem, Italy).

Stool: 270 Stool samples were cultured for Salmonella using Selenite F broth and Salmonella-Shigella agar (Liofilchem, Italy). 
Water: About $500 \mathrm{ml}$ of portable water taken from wells, standpipes, ponds and sachet (commercially packaged water in sachets) were filtered through sterile Whatman filter paper into a sterile vacuum flask. The whatman filter paper was then immersed in Selenite-F broth and incubated overnight at $37^{\circ} \mathrm{C}$. It was then sub-cultured onto Salmonella-Shigella agar (Liofilchem, Italy) and incubated overnight.

\section{Identification and isolation of Salmonella}

Growths that occurred in the cultural processes were identified by biochemical tests and confirmed by Vitek 2 . The antimicrobial susceptibility of the isolates were determined by the Kirby-Bauer disc diffusion method and the Minimum inhibitory (MIC) was determined by Vitek 2. Extended spectrum B-lactamase (ESBL) production of the isolates was determined using the double disc synergy test on Muller-Hinton agar.

\section{Results}

Fifty four (54) Salmonella strains were isolated from 464 samples of blood and stool tested, giving Salmonella prevalence of 11.6\%. Typhoidal and Non-typhoidal Salmonellae were isolated with Salmonella Enterica (30\%) being the most common isolate, followed by Salmonella Typhimurium (24\%) and (15\%) for Salmonella Enteritidis as indicated in Figure 1.

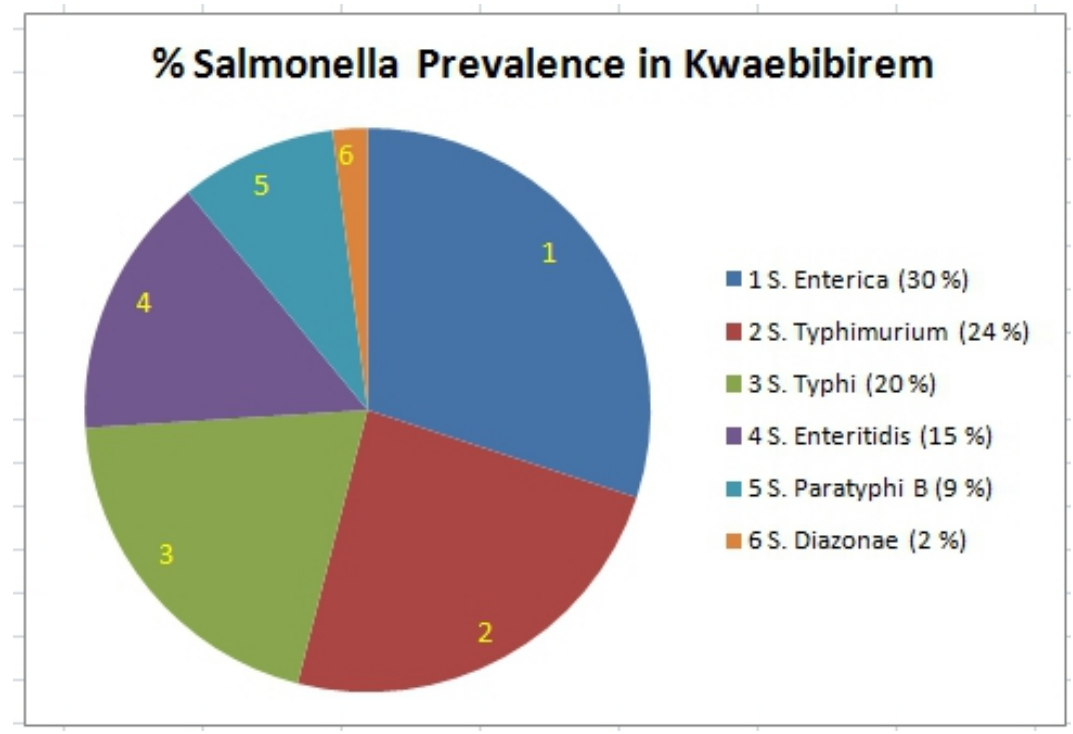

Figure 1 Species prevalence of Salmonella in Kwaebibirem district

The results indicate that Akwatia recorded the highest number of isolates $15(27.8 \%)$. This was followed by Asamankese with eight isolates (14.9\%) and Kade with four isolates (7.4\%). Of the 15 isolates obtained from 
humans in Akwatia, 5 were $S$. Enterica, 3 were $S$. Enteritidis and 3 for $S$. Typhimurium and 2 each of S.Paratyphi B and S. Typhi were isolated. Five isolates were obtained from dug-out wells sampled. No isolates were obtained from pipe-borne water, sachets water, and streams sampled. Salmonella isolates were obtained from many more communities where one isolate each was obtained from Abenaso Nkwanta, Abomasu, Adwafoakwa, Afosu, Akroso and many other towns indicating wide spread of the various Salmonellae in the area of study.

Table 1 Locality from which Salmonella was isolated and number isolated

\begin{tabular}{|c|c|c|c|c|c|c|c|c|}
\hline Locality & $\begin{array}{c}\text { S. } \\
\text { Diarizon } \\
\text { ae }\end{array}$ & $\begin{array}{l}\text { S.Ente } \\
\text { rica }\end{array}$ & $\begin{array}{l}\text { S.Enter } \\
\text { itidis }\end{array}$ & $\begin{array}{c}\text { S.Paraty } \\
\text { phi B }\end{array}$ & $\begin{array}{l}\text { S.Ty } \\
\text { phi }\end{array}$ & $\begin{array}{l}\text { S.Typhim } \\
\text { urium }\end{array}$ & $\begin{array}{c}\text { Tot } \\
\text { al }\end{array}$ & $\%$ \\
\hline Akwatia & & 5 & 3 & 2 & 3 & 7 & $\begin{array}{r}15( \\
5) \\
\end{array}$ & $\begin{array}{l}33 . \\
9 \% \\
\end{array}$ \\
\hline Asamankese & & 3 & 3 & & 1 & 1 & 8 & $\begin{array}{l}13 . \\
6 \%\end{array}$ \\
\hline Kade & & 3 & & & & 1 & 4 & $\begin{array}{c}6.8 \\
\%\end{array}$ \\
\hline Boadua & & 1 & 1 & & & 1 & 3 & $\begin{array}{l}5.1 \\
\%\end{array}$ \\
\hline Abaam & & & & & 1 & 1 & 2 & $\begin{array}{c}3.4 \\
\%\end{array}$ \\
\hline $\begin{array}{l}\text { Akwatia } \\
\text { Manso }\end{array}$ & & & & & 1 & 1 & 2 & $\begin{array}{l}3.4 \\
\% \\
\end{array}$ \\
\hline Okumaning & & 1 & & & 1 & & 2 & $\begin{array}{l}3.4 \\
\%\end{array}$ \\
\hline Pramkese & 1 & & & 1 & & & 2 & $\begin{array}{c}3.4 \\
\%\end{array}$ \\
\hline $\begin{array}{l}\text { Abenaso } \\
\text { Nkwanta }\end{array}$ & & 1 & & & & & 1 & $\begin{array}{l}1.7 \\
\% \\
\end{array}$ \\
\hline Abomosu & & & 1 & & & & 1 & $\begin{array}{l}1.7 \\
\%\end{array}$ \\
\hline $\begin{array}{c}\text { Adwafoakw } \\
\text { a }\end{array}$ & & & & & 1 & & 1 & $\begin{array}{l}1.7 \\
\% \\
\end{array}$ \\
\hline Afosu & & & & & 1 & & 1 & $\begin{array}{l}1.7 \\
\%\end{array}$ \\
\hline Akroso & & 1 & & & & & 1 & $\begin{array}{l}1.7 \\
\%\end{array}$ \\
\hline $\begin{array}{c}\text { Akyem } \\
\text { Tweapease }\end{array}$ & & & & 1 & & & 1 & $\begin{array}{l}1.7 \\
\%\end{array}$ \\
\hline Akyinso & & & & & 1 & & 1 & $\begin{array}{l}1.7 \\
\%\end{array}$ \\
\hline Amanfrom & & & & & 1 & & 1 & $\begin{array}{l}1.7 \\
\%\end{array}$ \\
\hline $\begin{array}{l}\text { Amantem } \\
\text { Nkwanta }\end{array}$ & & & & & & 1 & 1 & $\begin{array}{l}1.7 \\
\% \\
\end{array}$ \\
\hline Amonom & & & & 1 & & & 1 & $\begin{array}{l}1.7 \\
\%\end{array}$ \\
\hline
\end{tabular}




\begin{tabular}{|c|c|c|c|c|c|c|c|c|}
\hline $\begin{array}{c}\text { Apinamang } \\
\text { Brekumanso } \\
\text { Zongo }\end{array}$ & & & & & & 1 & 1 & $\begin{array}{c}1.7 \\
\%\end{array}$ \\
\hline Dwenase & & 1 & & & & & 1 & $\begin{array}{c}1.7 \\
\%\end{array}$ \\
\hline Osenase & & & & & 1 & & 1 & $\begin{array}{c}1.7 \\
\%\end{array}$ \\
\hline Staff Village & & & & & & 1 & 1 & $\begin{array}{c}1.7 \\
\%\end{array}$ \\
\hline Topremang & & & & & & 1 & 1 & $\begin{array}{c}1.7 \\
\%\end{array}$ \\
\hline TOTAL & $\mathbf{1}$ & $\mathbf{1 6}$ & $\mathbf{8}$ & $\mathbf{5}$ & $\mathbf{1 2}$ & $\mathbf{1 7}$ & $\mathbf{5 9}$ & $\begin{array}{c}\mathbf{1 0 0} \\
\mathbf{\%}\end{array}$ \\
\hline
\end{tabular}

()$=$ number of organisms isolated from water

Patients in the 6-15 year age group were most affected followed by 1630 year age group. The mean age of affected patients was 18years in an age range of 3-74 years. More females (55.6\%) were infected than males (44.4\%) with Salmonella. Details are shown in Table 2.

Table 2 Distribution of Salmonella species isolates in relation to demographic characteristics of infected patients in Kwaebibirem District.

\begin{tabular}{|c|c|c|c|c|c|c|c|}
\hline \multirow[b]{2}{*}{ Isolates } & \multicolumn{2}{|c|}{$\begin{array}{c}\text { Typhoidal } \\
\text { Salmonellae }\end{array}$} & \multicolumn{4}{|c|}{ Non-Typhoidal Salmonellae } & \multirow[b]{2}{*}{$\begin{array}{c}\text { Total } \\
54(100 \\
\%)\end{array}$} \\
\hline & $\begin{array}{c}\text { S. } \\
\text { Typhi } \\
11(20 \\
\%)\end{array}$ & $\begin{array}{c}\text { S. } \\
\text { Paratyp } \\
\text { hi B } \\
5(9 \%)\end{array}$ & $\begin{array}{c}\text { S. } \\
\text { Typhimur } \\
\text { ium } \\
13(24 \%)\end{array}$ & $\begin{array}{c}\text { S. } \\
\text { Enteri } \\
\text { ca } \\
16(30 \\
\%)\end{array}$ & $\begin{array}{c}\text { S. } \\
\text { Enteriti } \\
\text { dis } \\
8(15 \%)\end{array}$ & $\begin{array}{c}\text { S. } \\
\text { Diarizo } \\
\text { nae } \\
1(2 \%)\end{array}$ & \\
\hline \multicolumn{8}{|l|}{ Age groups } \\
\hline $0-5$ & 1 & 0 & 1 & 1 & 2 & 0 & $\begin{array}{c}5(9.3 \% \\
)\end{array}$ \\
\hline $6-15$ & 7 & 2 & 6 & 6 & 1 & 1 & $\begin{array}{c}23(42.6 \\
\%)\end{array}$ \\
\hline $16-30$ & 1 & 2 & 4 & 5 & 4 & 0 & $\begin{array}{c}16(29.6 \\
\%)\end{array}$ \\
\hline $31-50$ & 1 & 1 & 1 & 3 & 1 & 0 & $\begin{array}{c}7(13.0 \\
\%)\end{array}$ \\
\hline $51+$ & 1 & 0 & 1 & 1 & 0 & 0 & $\begin{array}{c}3(5.6 \% \\
\quad\end{array}$ \\
\hline \multicolumn{8}{|c|}{ Sex } \\
\hline Male & 5 & 1 & 5 & 9 & 3 & 1 & $\begin{array}{c}24(44.4 \\
\%)\end{array}$ \\
\hline Female & 6 & 4 & 8 & 7 & 5 & 0 & $\begin{array}{c}30(55.6 \\
\%)\end{array}$ \\
\hline \multicolumn{8}{|c|}{ Sample type } \\
\hline
\end{tabular}




\begin{tabular}{|c|c|c|c|c|c|c|c|}
\hline Blood & 11 & 4 & 0 & 0 & 0 & 0 & $\begin{array}{c}15(27.8 \\
\%)\end{array}$ \\
\hline Stool & 0 & 1 & 13 & 16 & 8 & 1 & $\begin{array}{c}39(72.2 \\
\%)\end{array}$ \\
\hline Water & 1 & 0 & 4 & 0 & 0 & 0 & $\begin{array}{c}5(9.3 \% \\
)\end{array}$ \\
\hline
\end{tabular}

\section{Antimicrobial susceptibility patterns of the isolates}

The isolates exhibited high resistance to some antibiotics tested ranging from $69.5 \%$ to $90 \%$ against Ampicillin, Piperacillin and cotrimoxazole. Isolate of Salmonella Paratyphi B and Salmonella Diarizonae were most resistant, where none at all was susceptible to Ampicillin, Piperacillin and co-trimoxazole.

Resistance results were varied against amikacin and gentamycin, the amoniglycosides tested. Thirty one $(52.5 \%)$ isolates were susceptible to amikacin at MIC of $<=2 \mathrm{ug} / \mathrm{ml}$ and $51(86 \%)$ isolates were sensitive to Gentamycin at $<=1 \mathrm{ug} / \mathrm{ml}$. Similar results were obtained against ciprofloxacin and norfloxacin the quinolones tested, where $56(95 \%)$ isolates were sensitive to ciprofloxacin at MIC of $<=0.25 \mathrm{ug} / \mathrm{m}$. Varied sensitivity results were obtained against the cephalosporins tested, but no isolate was resistant to meropenem and imipenem the cabapenems. The detailed results of the resistant proportions are in figure 2 and the MIC results are in table 3.

Figure 2 Antimicrobial susceptibility patterns of Salmonella isolates in Kwaebibirem

\section{District}

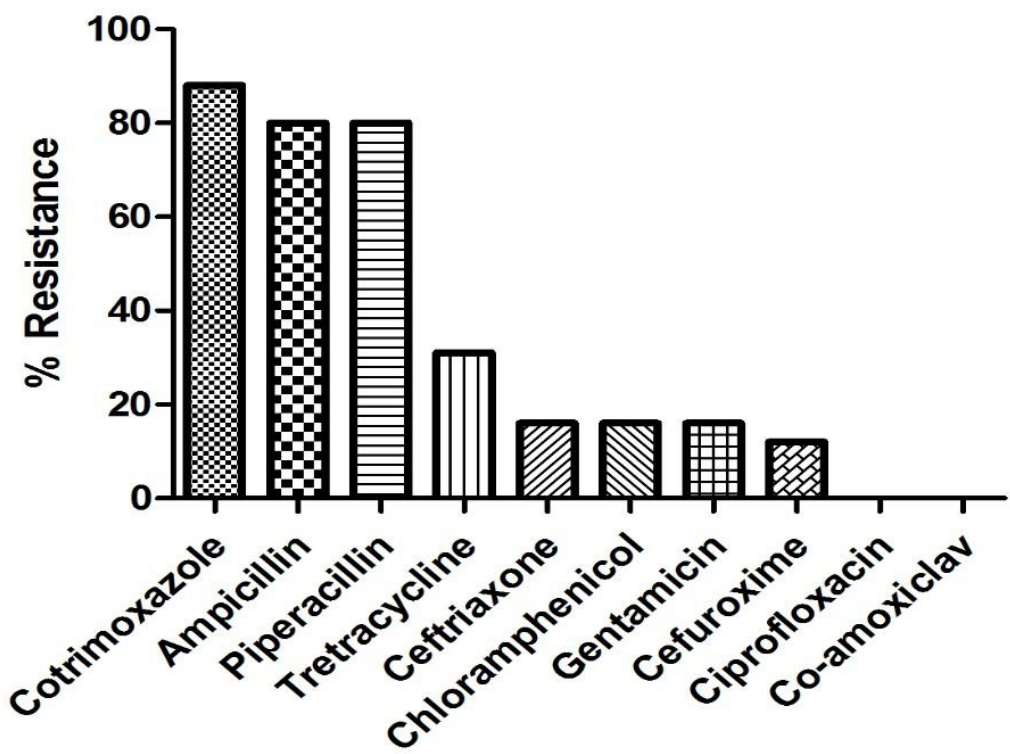

Antibiotics 
Table 3 Minimum inhibitory concentrations (MICs) of 59 Salmonella isolates in Kwaebibirem

\begin{tabular}{|c|c|c|c|}
\hline Antibiotics & $\operatorname{MIC}(\mu \mathrm{g})$ & Interpretation & No of isolates (\%) \\
\hline \multirow[t]{2}{*}{ Ampicillin } & $\geq 32$ & $\mathrm{R}$ & $41(69)$ \\
\hline & 16 & I & $2(3)$ \\
\hline \multirow[t]{2}{*}{ Piperacillin } & $\geq 128$ & $\mathrm{R}$ & $41(69)$ \\
\hline & 64 & I & $2(3)$ \\
\hline \multirow[t]{2}{*}{ Piperacillin/tazobactam } & $\leq 128$ & $\mathrm{R}$ & $43(73)$ \\
\hline & 32 & I & $5(8)$ \\
\hline \multirow[t]{4}{*}{ Amoxicillin/clavulanic acid } & $\leq 2$ & $S$ & $18(31)$ \\
\hline & 4 & S & $9(16)$ \\
\hline & 8 & S & $29(49)$ \\
\hline & 16 & I & $3(5)$ \\
\hline \multirow[t]{2}{*}{ Cefazolin } & $\leq 4$ & S & $30(51)$ \\
\hline & $8(19)$ & S & $19(32)$ \\
\hline Cefoxitin & $\leq 4(55)$ & S & $55(93)$ \\
\hline Cefotaxime & $\leq 1(53)$ & S & $53(90)$ \\
\hline Ceftazidime & $\leq 1(58)$ & $S$ & $58(98)$ \\
\hline Ceftriaxone & $\leq 1$ & S & $43(73)$ \\
\hline \multirow[t]{2}{*}{ Cefuroxime } & $\leq 1$ & S & $47(80)$ \\
\hline & 16 & I & $6(10)$ \\
\hline Cefepime & $<1$ & $\mathrm{~S}$ & $59(100)$ \\
\hline Imipenem & $\leq 1$ & $\mathrm{~S}$ & $59(100)$ \\
\hline Meropenem & $\leq 1$ & S & $59(100)$ \\
\hline \multirow[t]{3}{*}{ Amikacin } & $\leq 2$ & $S$ & $31(53)$ \\
\hline & $4(27)$ & S & $27(46)$ \\
\hline & $8(1)$ & I & $1(2)$ \\
\hline \multirow[t]{2}{*}{ Gentamycin } & $\leq 1$ & S & $51(86)$ \\
\hline & $\geq 16$ & $\mathrm{R}$ & $8(13)$ \\
\hline \multirow[t]{2}{*}{ Ciprofloxacin } & $\leq 0.25$ & $\mathrm{~S}$ & $56(95)$ \\
\hline & $0.5(3)$ & S & $3(5)$ \\
\hline \multirow[t]{2}{*}{ Norfloxacin } & 0.5 & $\mathrm{~S}$ & $46(78)$ \\
\hline & 2 & S & $13(22)$ \\
\hline \multirow[t]{3}{*}{ Tetracycline } & $\leq 1(41)$ & S & $41(69)$ \\
\hline & $4(2)$ & I & $2(3)$ \\
\hline & $\geq 16(16)$ & $\mathrm{R}$ & $16(27)$ \\
\hline \multirow[t]{2}{*}{ Trimethoprim/sulfamethoxazole } & $\leq 20(14)$ & S & $14(24)$ \\
\hline & $\geq 320$ & $\mathrm{R}$ & $45(76)$ \\
\hline
\end{tabular}

$\mathrm{S}=$ Susceptible; $\mathrm{I}=$ intermediate; $\mathrm{R}=$ Resistance

\section{Discussions}

Human Salmonella carriers are often sources of human Salmonella spread, so also are contaminated water and food. The patients and carriers spread the disease through the contamination of food and water they handle (Gupta and Garg, 2014).

This study attempted to establish the prevalence of Salmonella infection among patients attending St. Dominic Hospital, the sources of the infection and the antimicrobial susceptibility patterns of the isolates. High 
prevalence of salmonella infection was detected among patients attending the St Dominic Hospital and also in well-water. There were 54 Salmonella isolates obtained from different samples of patients, where 15 (28\%) came from blood samples and 39 (72 \%) were isolated from stool samples. Five (5) Salmonella isolates were isolated from dug-out well water samples. Salmonella prevalence was $11.0 \%$ among the patients and $2.7 \%$ in water samples. The high prevalence of Salmonellla among patients in the district perpetuate the disease in the district through indiscriminate defaecation in the environment (Levantes et al., 2012). Rain water washes the faeces from upland into the low lying open du-out wells (Abdulkadir et al., 2014). Some wells too are sited close to latrines and seepage from the latrines contaminates these well waters with faecal microbes including Salmonella (Abdulkadir et al., 2014). The majority of inhabitants in Kwaebibirem district depend on communal Kumasi Ventilated Improved Pit (KVIP) type latrines whiles some inhabitants depend on household pit latrines. The availability of toilets is about $60 \%$ (http://kwaebibirem.ghanadistricts.gov.gh/). Provision of communal KVIP has its access restricted by the payment of a token, a measure which has reduced its usage, so some of the populace defaecate indiscrimately in the nearby bushes. Gold and diamond mining in addition to sand and stone quarrying activities lead to silting of many streams and rivers, (especially the Birim River), which formerly were sources of drinking water for the inhabitants but these rivers are now polluted leading to the dependence of dugout wells. Urbanization has hampered the district's ability to control solid and liquid waste disposal leading to the creation of large garbage hills which also serve as sites for defaecation in the towns (Addo et al., 2014). Rain water flows from these garbage sites and the neighbouring thickets into low lying rivers and wells contaminating them with enteric bacteria. These activities disseminate Salmonella causing gastroenteritis and typhoid in the district (Attua et al., 2015). Not all Salmonellae serotypes found in the environments are the same as those isolated from humans (Setti et al., 2009) because some isolates are associated with animals (Levantes et al., 2012; Andoh et al., 2016). In this present study well water samples yielded Salmonella serovars commonly associated with human clinical disease (Abdulkadir et al., 2014). This was observed probably because pit latrines sited in close proximity to dug-out wells leak into the water (Karkey et al., 2016) creating a source of infection to the people who drink from them. It was unclear when Salmonella was not isolated from the River waters sampled. But it is perhaps river water runs and the contaminants are washed downstream away from the point of contamination. Dug-out wells retain the contaminants and also serve as culture medium which increase them to infectious dosages (Nwaiwu and Nwachukwu, 2016). 
Studies in Nigeria found well-water contaminated with bacteria with counts ranging from 100 to $800 \mathrm{col} / 100 \mathrm{ml}$ of water (Olabisi et al., 2008) and in Tanzania surface waters contaminated with Salmonella (Lyimo et al., 2016) had results similar to the Kwaebibirem study.

Salmonella infection is treated with an appropriate antibiotic (de Jong et al., 2014), but recent increases in antibiotic-resistant bacteria have prompted routine surveillance of microbial populations to determine the appropriate antibiotic to choose (de Jong et al., 2014; Eze et al., 2015). The 46 Salmonella isolates of clinical origin and five (5) from water in this present study were examined for their susceptibility to various antibiotics and extended spectrum beta-lactamase production (Tansarli et al., 2014; Harish and Menezes, 2015). There were varied susceptibility results to the antibiotics tested as presented in figure 2 and the MIC in Table 2. However, no strain was found to produce extended spectrum beta lactamase (ESBL), perhaps because ESBLs are associated with nosocomial infections contrary to Salmonella infections which are community acquired (Pitout et al., 2005). High proportions of Salmonella were susceptible to ciprofloxacin and norfloxacin posing no resistant problems to Quinolone in the Kwaebibirem district as was obtained elsewhere (Humphries and Schuetz, 2015; Kariuki et al., 2015; Rodriguez-Martinez et al., 2015; Lyimo et al., 2016). So also the susceptibility of the isolates to Carbapenems (Imepenem and Meropenem) tested had no resistant strains. These antibiotics are not common in the Kwaebibirem district community because they are relatively more expensive and beyond the reach of most inhabitants. Chloramphenicol is still a drug to consider in the treatment of Salmonella infections as the resistance proportion was less than $20 \%$ in the study area. Pharmacy and chemical shops would normally not stock such drugs because they would not sell out quickly so would not be abused because many people cannot afford to purchase them.

\section{Conclusion}

Prevalence of Salmonella infection in Kwabibirem District is high recording about $12 \%$. The disease affects both male and females of all ages, but the youth (average age of 18years) are most affected. Well-waters taken from the communities were contaminated with Salmonella, along with a high total viable enteric bacterial counts, suggesting fecal contamination of the Wells.

\section{Acknowledgement}

The authors are thankful to the authorities of St. Dominic Hospital for allowing this study to be conducted in their Clinical Laboratory. 


\section{References:}

1. Abdulkadir R.S., Mahmoud A.M., Adnan A., Shamsuddeen U., Adamu R.T. and I Y. ( 2014) Effect of Pit Latrine Leaks on Shallow Well Water. International Journal of Microbiology and Application 1, 46-51.

2. Addo H., Addo K. and Langbong B. (2014) Sanitation and its Impact on the Bacteriological Quality of Water: A Study in Three Communities in Ghana. African Journal of Food, Agriculture, Nutrition and Development 13, 8258-8272.

3. Andoh L., Dalsgaard A., Obiri-Danso K., Newman M., Barco L. and Olsen J. (2016) Prevalence and antimicrobial resistance of Salmonella serovars isolated from poultry in Ghana. Epidemiology \& Infection, 112.

4. Attua E.M., Annan S.T. and Nyame F. (2015) Water quality analysis of rivers used as drinking sources in artisanal gold mining communities of the Akyem-Abuakwa area: A multivariate statistical approach. Ghana Journal of Geography 6, 24-41.

5. de Jong A., Smet A., Ludwig C., Stephan B., De Graef E., Vanrobaeys M. and Haesebrouck F. (2014) Antimicrobial susceptibility of Salmonella isolates from healthy pigs and chickens (2008-2011). Veterinary microbiology.

6. Eze E., Ocean H. and Eze C. (2015) Prevalence of beta-lactamases in Salmonella and Shigella species in different hospitals in Anyigba, Kogi State, Nigeria. African Journal of Microbiology Research 9, 180184.

7. Harish B.N. and Menezes G.A. (2015) Determination of Antimicrobial Resistance in Salmonella spp. In Salmonella, pp. 47-61: Springer.

8. Humphries R.M. and Schuetz A.N. (2015) Antimicrobial Susceptibility Testing of Bacteria That Cause Gastroenteritis. Clinics in Laboratory Medicine.

9. Kariuki S., Gordon M.A., Feasey N. and Parry C.M. (2015) Antimicrobial resistance and management of invasive Salmonella disease. Vaccine.

10. Karkey A., Jombart T., Walker A.W., Thompson C.N., Torres A., Dongol S., Thieu N.T.V., Thanh D.P., Ngoc D.T.T. and Vinh P.V. (2016) The ecological dynamics of fecal contamination and Salmonella Typhi and Salmonella Paratyphi A in municipal Kathmandu drinking water. PLoS Negl Trop Dis 10, e0004346.

11. Levantes C., Bonadonna L., Grohmann B., Toze S. and Tandoi V. (2012) Salmonella in surface and drinking water: Occurrence and water-mediated transmission. Food Research International 45 587-602. 
12. Lyimo B., Buza J., Smith W., Subbiah M. and Call D.R. (2016) Surface waters in northern Tanzania harbor fecal coliform and antibiotic resistant Salmonella spp. capable of horizontal gene transfer. African Journal of Microbiology Research 10, 348-356.

13. Nwaiwu O. and Nwachukwu M. (2016) Detection and Molecular Identification of Persistent Water Vessel Colonizing Bacteria in a Table Water Factory in Nigeria. British Microbiology Research Journal 13, 1.

14. Olabisi O.E., Awonusi A.J. and Adebayo O.J. (2008) Assessment of bacteria pollution of shallow well water in Abeokuta, Southwestern Nigeria. Life Science Journal. Vol.5 No.1, 2008, 59-65.

15. Pitout J.D., Nordmann P., Laupland K.B. and Poirel L. (2005) Emergence of Enterobacteriaceae producing extended-spectrum betalactamases (ESBLs) in the community. J Antimicrob Chemother 56 52-59.

16. Rodriguez-Martinez J.-M., Machuca J., Calvo J., Diaz-de-Alba P., Rodríguez-Mirones C., Gimeno C., Martinez-Martinez L. and Pascual Á. (2015) Challenges to accurate susceptibility testing and interpretation of quinolone resistance in Enterobacteriaceae: results of a Spanish multicentre study. Journal of Antimicrobial Chemotherapy, dkv059.

17. Setti I., Rodriguez-Castro A., Pata M.P., Cadarso-Suarez C., Yacoubi B., Bensamel L., Moukrim A. and Martinez-Urtaza J. (2009) Characteristics and dynamics of Salmonella contamination along the coast of Agadir, Morocco. Applied and Environmental Microbiology Vol. 75, pp. 7700-7709.

18. Tansarli G.S., Poulikakos P., Kapaskelis A. and Falagas M.E. (2014) Proportion of extended-spectrum $\beta$-lactamase (ESBL)-producing isolates among Enterobacteriaceae in Africa: evaluation of the evidence-systematic review. Journal of Antimicrobial Chemotherapy, dkt500. 